\title{
The Popular Movement Dimensions of Contemporary Militant Islamism: Socio-Spatial Determinants in the Cairo Urban Setting*
}

\author{
SALWA ISMAIL \\ University of Exeter
}

This paper is a revisiting of the question of contemporary Islamism in Egypt. Its purpose is to rethink the main arguments and explanatory frameworks relating to Islamist activism in general and the militant and violent type in particular. It presents some new propositions about the phenomenon and provides elements for a deeper understanding. This revisiting is undertaken in light of certain developments over the last decade or so, which may be summarised as follows: 1) the heightening of Islamist violence, marked by confrontations with the government in and around Cairo and in the provinces of Upper Egypt ${ }^{1} ; 2$ ) the emergence of clear socio-spatial dimensions to Islamist activism. For the purposes of this article, my analysis pertains to these developments in the greater Cairo area. ${ }^{2}$

The paper is guided by several interrelated aims, some of which are given only preliminary attention here. First, it points to the links between Islamist

\footnotetext{
*An earlier version of this article was presented at the Annual Meeting of the British Society for Middle Eastern Studies, Selly Oak Colleges, Birmingham, July 5-7, 1998. I thank Brian Aboud and Mohamad Salah Omri for their comments on earlier drafts of the article. I also thank Diya' Rashwan for sharing with me his insights on Islamist activism in Egypt. Finally, I am grateful to the anonymous readers who provided helpful and insightful suggestions for revisions.

1 The 1990s have seen an intensification of violent clashes between the Islamists and the government, claiming over one thousand lives. The Islamist attacks have been aimed particularly at the tourism sector and the police. More than a hundred police officers and soldiers have been killed. For more details, see the annual reports of al-Taqrir al-Istratiji al-Arabi (The Arab Strategic Report). See also Nabil Abd al-Fatah and Diya' Rashwan, Taqrir al-Hala al-Diniya fi Misr 1995 (Report on the State of Religion in Egypt 1995) (Cairo: Centre for Political and Strategic Studies, 1997).

2 The rise of al-Jama ${ }^{c}$ a al-Islamiya in the Upper Egypt governorates of Qena, Asyut, Suhaj, Minya and Aswan must be examined in relation to the social fabric and spatial organisation of their cities and towns. The complexity of social organisation based on tribe and family and the hierarchies characterising social, economic, and political positions in the various provinces have yet to be studied in a comprehensive manner, and are beyond the scope of this paper. See Nazih Ayubi, Political Islam (London: Routledge, 1991), and Mamun Fandy, "Egypt's Islamic Group: Regional Revenge," Middle East Journal 48, 4 (1994): 607-25.
} 
action, on one hand, and a particular social geography of the city and the historical modes of urban organisation, on the other. Here, I draw attention to the history of urban activism in the popular quarters of the city, underlining the role of popular classes in politics, the grounding of their activism in the social structures of the neighbourhoods and their patterns of organisation. Second, it outlines certain characteristics of the present urban context; specifically the informal housing communities and the social landscape characterising them. The argument here is that Islamism has found a home in these communities because their spatial, social, cultural, and economic characteristics have contributed to their emergence as "spheres of dissidence." 3 Third, it examines the Islamist modes of implantation and action and the ways in which these are interwoven with the space, as exemplified by the informal housing communities of Ain Shams and Imbaba in greater Cairo. Fourth, it highlights the importance of certain contemporary Islamist practices, which recall earlier forms of social organisation and regulation. Fifth, it situates Islamist activism within an overall framework, which takes into account the variables outlined above in addition to the role of ideological practices in mobilising support. In this regard, I will underline the limits to mobilisation which arise out of the Islamists' articulation of the principle of "enjoining good and forbidding evil."

The central argument is that militant Islamism has developed as an appropriation of spaces that have emerged in the ongoing processes of urban growth and expansion. There are indications that the new landscape does not represent rupture with social traditions and popular modes of life, but is, rather, a variation on the historically evolving urban tapestry. In socio-spatial terms, the Islamists are "of" the popular classes, diverging from them only in some of their radical ideological practices.

The paper is divided into five sections. Section one highlights certain elements in the explanatory frameworks used in relation to militant Islamism. Section two provides a brief historical overview of Cairo's urban social organisation. Section three sketches the new popular neighbourhoods, drawing a composite image of their social space. Section four outlines the Islamist mode of implantation in the new quarters. Section five highlights the popular movement dimensions of Islamist activism and the limitations of their ideological practices in the new quarters. The conclusion attempts to draw out the case for and against the development of militant Islamism as a full-fledged movement of the popular classes.

\section{A BRIEF OVERVIEW OF CONTEMPORARY ISLAMISM}

AS A CONTESTATION MOVEMENT

Militant Islamism is conventionally associated, at the ideological level, with Egyptian radical thinker Sayyid Qutb, and at the level of practice, with the 1970s

3 This formulation is borrowed from Sami Zubaida, "Class and Community in Urban Politics," in État et ville, et mouvements sociaux au Maghreb et au Moyen-Orient, eds., Kenneth Brown et al. (Paris: L'Harmmattan, 1989), 70. 
groups influenced by his ideas. Among the earliest of these groups were alFanniya al-Askariya (the Technical Military Academy) and al-Takfir wa al-Hijra (Excommunication and Flight), while the later ones, which continue to be active to this date, are al-Jihad Organisation and al-Jama ${ }^{c}$ a al-Islamiya (the Islamic Group). ${ }^{4}$ These groups share what is commonly referred to as a "Jihadist" ideology. The main tenets of this ideology revolve around the idea of restoring hakimiyya (God's governance) and the evaluative assessment of present-day society as jahiliyya (the state of ignorance before the advent of Islam). The concept of jihad (struggle) is central to their militant ideology, serving to justify the use of violence as a mode of action against state and society. The purpose of jihad is to establish the Islamic state and apply the shari ${ }^{c}{ }^{5}{ }^{5}$ These two objectives are shared with moderate Islamist groups such as the Muslim Brotherhood Organisation.

Studies of these militant groups and their ideologies have generated typologies of organizations and individuals in their attempts to explain the nature of the movement and provide a framework for understanding. It is not my intention here to review the now immense volume of literature on the topic. ${ }^{6}$ Rather, I will briefly recall the main contours of two key approaches in the literature on this subject. The first takes Islam as a starting point, and bases itself on the history of Islamic ideas. Through this prism, the movements appear as an expression of unchanging principles which guide the believers; hence their fundamentalism. ${ }^{7}$ This corresponds to the revival thesis advanced by Sivan and others. Within this same approach, a more nuanced view is given in the reform thesis, which sees in Islamism the articulation of the religion's inherent, transformative potential. ${ }^{8}$ The approach as a whole tends to attribute continuity to Islamic ideas and thought, and posits them as the embodiment of some religious essence.

${ }^{4}$ On the first two groups see Saad Eddine Ibrahim, "Islamic Militancy as a Social Movement: The Case of Two Groups in Egypt," in The Islamic Resurgence in the Arab World, ed. Ali E. Hillal al-Dessouki (New York: Praeger, 1982), 117-37. The Jihad and the Jama a groups formed an alliance in 1980, which was forged by Abd al-Salam Farag of Jihad and Karam Zuhdi of al-Jama a. The alliance was responsible for the assassination of President Sadat, but broke down in 1984. More recently, leading Jihad figures such as Abud al-Zumur were reconciled with the Jama ${ }^{c}$ and rejoined its ranks. The Jihad originated in Cairo and carried out most of its activities there. The Jama a's roots are in Upper Egypt. The two groups differ in modes of operation. The Jihad's membership is smaller, its activities more concentrated and its violence more targeted. The Jama a is more diffuse at each of these levels. For more details, see Abd al-Fatah and Rashwan eds., Taqrir al-Hala alDiniya 1995, 183-86.

5 For a discussion of the militant groups' ideological discourse, see Salwa Ismail, "Radical Islamism in Egypt: Discursive Struggle," Montreal Papers on the Contemporary Arab World (Montreal: Inter-university Consortium for Arab Studies, 1994).

${ }^{6}$ See Yvonne Haddad and John L. Esposito, The Islamic Revival since 1988: A Critical Survey and Bibliography (London: Greenwood Press, 1997).

${ }^{7}$ For examples of this approach see Emmanuel Sivan, Radical Islam: Medieval Theology and Modern Politics (New Haven: Yale University Press, 1985), and P.J. Vatikiotis, Islam and the State (London: Croom Helm, 1987), particularly chapter three.

${ }^{8}$ See R.H. Dekmejian, "Islamic Revival, Catalysts, Categories, and Consequences," in The Politics of Islamic Revivalism, ed. Shireen Hunter (Bloomington: Indianna University Press, 1988), 3 22, and John O. Voll, "Renewal and Reform in Islamic History: Tajdid and Islah," in Voices of Resurgent Islam, ed. John L. Esposito (New York: Oxford University Press, 1983), 32-47. 
The second approach is best described as the psychosocial model. Its earliest expression is found in studies of the socioeconomic background of the first generation of militant Islamists, who emerged on the scene in the 1970s. ${ }^{9}$ The model has yielded a socio-psychological profile of the ideal militant type: a recent migrant to the city, highly educated, a disenchanted product of modernisation. This perspective described the relationship between the movement and its context as being based on factors such as social dislocation and alienation. Within this conceptual framework the Islamists represent a rejection of their social environment. They occupy a vanguard role by virtue of their distinction from the rest of society. This approach's emphasis on Islamists' elitist ideology and high level of educational achievement leads to a downplaying of the movement's popular dimensions. In this vein, Hamied Ansari affirmed:

The militant view is confined to a segment of the population on the margin of society. It has no impact on the urban masses or traditional rural society. Islamic militancy is especially appealing to the young men or to the rural migrants who became caught in the web of an urban society whose most manifest feature is the unbridled consumerism resulting from the liberalization policy initiated by Sadat. To this segment of the population which is experiencing an acute sense of deprivation, the resort to Islam was more a sign of social protest than a way of life. ${ }^{10}$

In a more recent study, Saad Eddine Ibrahim noted changes in the social profile of the membership of Islamist groups: a decline in the percentage of university students active in militant groups, and an increase in the share of what he terms the lower middle class. ${ }^{11}$ Further, Ibrahim has included the "alienated masses" among those who suffer from relative deprivation. Although Ibrahim has adjusted the profile, the explanatory framework of the psychosocial approach remains intact. There are problems with this conceptual apparatus. First, it views the people as divorced from their social setting or, at least, psychologically removed from it. Thus, it leaves out both the efforts of the disaffected to create an alternative set of living conditions, and their engagement in the production of that environment. Second, the greater emphasis on psychological factors attracts attention away from the structures of social action which emerge in everyday life, and from those structures which can be recalled as acts of historical retrieval and remembering. As a result of these conceptual restrictions, we lose sight of the spaces of protest and the structures of oppositional action in which the people operate; by extension, we do not see in what

9 Saad Eddine Ibrahim, "Islamic Militancy as a Social Movement," and Hamied Ansari, "The Islamic Militants in Egyptian Politics," International Journal of Middle East Studies 16 (1984): $123-44$.

10 Ansari, "The Islamic Militants," 141.

${ }^{11}$ Saad Eddine Ibrahim, "The Changing Face of Egypt's Islamic Activism," in Security Challenges in the Mediterranean Region, eds. Roberto Aliboni, George Joffe and Tim Niblock (London: Frank Cass, 1996), 27-40. 
ways and under what terms the Islamist insertion into the popular spaces has occurred.

A number of studies have, however, paid attention to the issue of popular activism. Situating the Islamist challenge within a wider historical context, Afaf Lutfi al-Sayyid-Marsot analyzes contemporary Islamism as an urban protest movement. ${ }^{12} \mathrm{Al}$-Sayyid-Marsot shows how Islamic groups represent a type of collective action which involves popular mobilisation, and describes how this type of action is rooted in the changing dynamics of state-society relations in Egypt. These changes took place in the structures of mediation, whereby the role of the ulama (learned men of religion) as intermediaries and popular leaders was "devolved on new socially mobilised groups." ${ }^{13}$ Similarly, Guilain Denoeux recognised the importance of Islamic urban networks in the mobilisation of opposition against the state. ${ }^{14}$ However, in conceptual terms Denoeux alternates between the two approaches outlined above. In line with Saad Eddine Ibrahim, he emphasises that the ideological principles of the Islamist groups responded to the needs of uprooted, alienated, educated youths. ${ }^{15}$ At the same time, drawing on Emmanuel Sivan, he argues that the groups are a contemporary manifestation of the original founding experience of Islam, i.e., the hijra model (the flight of the prophet and the believers from Mecca to Medina). ${ }^{16}$

The approach developed in this article stresses the importance of sociospatial factors in analysing contemporary Islamism and in exploring the popular movement dimension of Islamist militant action. In other words, the study seeks to explore how the Islamists anchor themselves in certain spaces. One important aspect of my analysis is the study of the historical dimension of urban activism, in which activists draw on earlier experience and show where continuities and breaks occur. The attention given to space nuances the similarities and differences encountered in the urban landscape, both historically and in the contemporary period. This points to the need for comparative studies of old quarters in their evolution and in relation to the new popular quarters, including informal housing communities. As will be apparent from the analysis below, some characteristics of the old quarters and their social modes of organisation have persisted to the present. In addition, these have been transported to the new quarters and, in the process, have been reinvented and transformed. The comparative historical view helps locate contemporary Islamism within the developing socio-spatial configuration of the city. The approach I am proposing proceeds in a similar vein to the study of "comparative history of urban collec-

\footnotetext{
12 Afaf Lutfi al-Sayyid-Marsot, "Religion or Opposition? Urban Protest Movements in Egypt," International Journal of Middle East Studies 16 (1984): 541-52.

13 Ibid., 55

14 Guilain Denoeux, "Religious Networks and Urban Unrest: Lessons from Iranian and Egyptian Experiences," in The Violence Within: Cultural and Political Opposition in Divided Nations, ed. Kay B. Warren (Boulder: Westview Press, 1993), 123-55.

15 Ibid., $137 .{ }^{16}$ Ibid., 145.
} 
tive action" outlined by Edmund Burke III. ${ }^{17}$ Such a study is focused on the evolving patterns and forms of urban contestation, and on tracing the links between the changes in these forms, on the one hand, and the processes of social transformation, on the other. ${ }^{18}$

\section{POPULAR FORCES AND POWER RELATIONS IN THE CAIRO URBAN}

\section{SETTING: A BRIEF HISTORICAL OVERVIEW}

A central aim of this paper is to bring into focus the analysis of societal forms of organisation in explaining modes of contestation, including militant Islamism. The anchoring of Islamist forces in particular urban spaces with distinct characteristics can help account for the nature of their organisation and their patterns of action. Greater insights can be gained by situating this process within an historical context, in which specific groups acted as forces of contestation and stimulated urban unrest in various Middle Eastern countries and historical periods. ${ }^{19}$ This is not to argue that the contemporary Islamists are an extension of these earlier forces, but to draw out the importance of certain forms of social organisation which are reproduced or transformed over time, highlighting continuities as well as ruptures. This constitutes an element of a wider framework which can illuminate our understanding of one of the most important forces of contestation today: militant Islamism.

A starting point for reviewing city organisation in the Ottoman period (sixteenth to nineteenth centuries) is its subdivision into quarters, with territorial, social, and political boundaries. ${ }^{20}$ The basis of this division was residential, professional, and religious. In the popular quarters of Cairo, professional communities organised along craft lines, known as guilds, were juxtaposed to residential neighbourhoods. Superimposed on this framework was a religious type of organisation (primarily the sufi orders). The whole formed a complex urban network characterised by the overlapping of residential, professional, and communal affiliations, parts of an overall system of power and control with many layers. This same feature facilitated mobilisation of popular groups in times of

17 Edmond Burke III, "Towards a History of Urban Collective action in the Middle East: Continuities and Change, 1750-1980," in État, ville et mouvements sociaux au Maghreb et au MoyenOrient, eds. Kenneth Brown et al. (Paris: L'Harmmattan, 1989), 42-56.

18 Ibid., 44.

19 For a critical introduction to the literature on urban organisation, see R. Stephen Humphreys, Islamic History: A Framework for Inquiry (London: I. B. Tauris, 1995), chapter ten. See also Masahi Haneda and Toru Miura eds., Islamic Urban Studies: Historical Review and Perspectives (London: Kegan Paul International, 1994).

20 Recent literature on urbanism in Islamic history has questioned Orientalist scholarship on the idea of the Islamic city. The critique of orientalist urban studies is outside the immediate interest of this article. However, the questions raised in the ongoing debates have a direct bearing on how we view urban society in Middle Eastern countries. See ibid., and Kenneth Brown, "The Uses of a Concept: 'The Muslim City',' in Middle Eastern Cities in Comparative Perspective, eds. Kenneth Brown et al. (London: Ithaca Press, 1987), 73-81. 
crises. ${ }^{21}$ As André Raymond notes, “... the inscription of the political and social forces in the geography of the city ... was a fundamental phenomenon." 22

The guilds were more than mere economic units; they had rules and structures of a social and political nature, with their heads (shaykhs) being chosen by the membership and confirmed by the wali (governor). The shaykh was in charge of collecting taxes, overseeing rules of apprenticeship, and maintaining order. ${ }^{23}$ In addition, some shaykhs were heads of sufi orders based in the quarters. An added dimension was the presence of organised youths or gangs with links to these orders. Their names varied from the pejorative 'ayyarun and $z u^{c} r$, to the more positive, such as futuwwa. ${ }^{24}$

How did all of this fit into the system of social and political control? In principle, the quarters were headed by a shaykh al-hara, who was the representative of the city governor and acted as an informant to authority. Other state agents included the muhtasib, who oversaw pricing in the market and the preservation of public morality. Another layer of state-society mediation and control was occupied by the official ${ }^{\text {ulama. }}{ }^{25}$

The positioning of the futuwwah, shaykh al-hara, muhtasib, ${ }^{\mathrm{c}}$ alim, and sufi leader was not static. The local groups extended their powers over their quarters when the central administration was weak. ${ }^{26}$ Popular forces, particularly the $\mathrm{zu}^{\mathrm{c}} \mathrm{r}$, rose in contestation at different periods and for various reasons. They also constituted a force to be mobilised by different contenders for power, including the state itself. During the Ottoman period, Raymond notes, governments sometimes sought their help, but more often looked upon them with

21 André Raymond, "Urban Networks and Popular Movements in Cairo and Aleppo at the End of the $18^{\text {th }}$ Century-Beginning of the $19^{\text {th }}$ Century," in The Proceedings of the International Conference on Urbanism in Islam (ICUTT), vol. 2 (Tokyo: The Middle East Culture Centre, 1989), 219-71.

22 Ibid., 263.

23 See Gabriel Baer, "Decline and Disappearance of Guilds," in Studies in the Social History of Modern Egypt (Chicago: The University of Chicago Press, 1982), 149-60. For a more nuanced approach drawing on extensive archival sources, see Juan R. I. Cole, Colonialism and Revolution in the Middle East: The Social and Cultural Origins of the Urabi Revolution (New Jersey: Princeton University Press, 1993). See also, Ehud Toledano, State and Society in mid-Nineteenth Century Egypt (Cambridge: Cambridge University Press, 1990).

24 Sawsan El-Messiri, "The Changing Role of the Futuwwa in the Social Structure of Cairo," in Patrons and Clients in Mediterranean Societies, eds. Ernest Gellner and John Waterbury (London: Duckworth, 1977), 239-53. On these groups in Cairo and Aleppo see Raymond, "Urban Networks." On the zu'r in Damascus see Miura Toru, "The Structure of the Quarter and the Role of the Outlaws: The Salihiya Quarter and the Zu'r Movement in Mamluk Period" in The Proceedings of the International Conference on Urbanism in Islam (ICUTT) vol. 3 (Tokyo: The Middle East Culture Centre, 1989), 402-37.

25 Afaf Loutfi El-Sayed, "The Role of the ulama in Egypt during the Nineteenth Century," in Political and Social Change in Modern Egypt, ed. P.M. Holt (London: Oxford University Press, 1968), 264-80.

26 Janet Abu Lughod, "The Islamic City-Historic Myth, Islamic Essence, and Contemporary Relevance," International Journal of Middle East Studies 19 (1987): 155-76. 
suspicion. ${ }^{27}$ The futuwwa gangs played an important role in mobilising the population of the quarters in the seventeenth and eighteenth centuries. It is these groups which responded to the wali's oppression, and which were mobilised under the leadership of the craft-sufi heads and other religious figures. ${ }^{28}$ Raymond affirms the gangs' role in making history through their collective power against the ruler. The threat to unleash gangs to loot and plunder forced rulers to retract from imposing higher taxes or raising prices. In a sense, the gangs preserved the moral economy of the city. ${ }^{29}$ In time, these popular groups became preliminary forces for contestation of and opposition to the French occupation (1798-1801), and were instrumental in the investiture of the country's leadership in the person of Muhammad Ali. ${ }^{30}$

After a strong central administration was put in place under Muhammad Ali in the nineteenth century, the political power of these forces waned, only to be reasserted at critical junctures. ${ }^{31}$ In any case, the terms of social control and local practices of power persisted. For example, the futuwwa- ${ }^{-}$alim coalition of the past was no longer operative, but, the futuwwa continued to influence the life of the quarter. ${ }^{32}$ Thus, while overt popular contestation was contained by an emerging strong state, socio-spatial factors allowed for continued autonomy and other forms of activism.

Here, we should turn to the social organisation of the quarters. ${ }^{33}$ Janet Abu Lughod stresses that within the terms of social and political organisation sketched above, the quarter acted as protector and constituted "defensible space." 34 This aspect of the quarter's character developed as a consequence of spatial and social organisation: spatial markers indicated where the public space ended and semi-private and private spaces began. At the hara (alley/neighbourhood) level, this spatial differentiation was expressed in a street system which included a central branch or street (darb), from which small alleys or passages called ' atfa branched into a zuqaq (dead-end alley). ${ }^{35}$ The hierarchical street system allowed for the maintenance of social autonomy and enforcement of social rules regarding gender relations.

27 André Raymond, "Quartiers et mouvements populaires au Caire au xviiième siècle," in Political and Social Change in Modern Egypt, ed. P.M. Holt (London: Oxford University Press, 1968), 111.

28 Ibid.

29 Although dealing with an earlier period, it is instructive to read Boaz Shoshan's study of the moral contract between ruler and ruled on the provision of subsistence goods. Shoshan, "Grain Riots and the "Moral Economy": Cairo 1350-1517," Journal of Interdisciplinary History 10, 3 (Winter 1980): 459-78.

30 Raymond, "Quartiers Populaires."

31 Juan Cole's study of the Urabi revolution crystallises the character of urban social organisation and the ways in which it framed collective action from the $1850 \mathrm{~s}$ on, culminating in the eruption of the events of 1881-82. Juan R. I. Cole, Colonialism and Revolution.

32 El-Messiri, "The Changing Role of the Futuwwa."

33 Abu Lughod, "The Islamic City." 34 Ibid.

35 Nawal al-Messiri-Nadim, "The Concept of the Hara: A Historical and Sociological Study of al-Sukkariya," Annales Islamologiques 15 (1979): 313-48. 
As a social unit the hara has persisted in the popular traditional quarters of the city, along with many of the rules and regulations which made the local neighbourhood operate as an extension of the family. In the twentieth-century context of rapid social transformation, which brought about new economic, social, and cultural developments for the popular classes to contend with, the old social practices grounded in space were reworked. Regulation of male-female relations and efforts to cope with new financial burdens of education and marriage were issues to be dealt with within the historically developed modes of socio-spatial interaction. Recent studies have shown us how this is accomplished ${ }^{36}$ and how the quarters, centred on alleys, continue to represent the everyday communities of the people, although the hara was officially abolished as an administrative unit and the office of shaykh discarded in $1962 .{ }^{37}$ The hara continues to exist as a social and territorial unit in the old quarters and, to a lesser extent, in other parts of the city. At the same time, the hara has undergone many changes. For example, Stauth notes that the integrative functions of hara social relations and institutions began to weaken with the introduction of factory relations into the workshop production of the quarters. ${ }^{38}$ As a result, the normatively grounded attitudes of reciprocity, arbitration and sexual segregation, which represent important rules in the construction of social and public life, required renegotiation. ${ }^{39}$ The modes of survival and transformation of the old popular quarters are instructive for our understanding of the new popular neighbourhoods.

In the post-1952 period, new residential and housing areas for the popular classes have sprung up through state planning and community efforts. These areas differ from the old popular quarters in terms of street layout and residential organisation. Those areas which emerged as a result of state planning were mainly large industrial zones with popular housing units (masakin sha biya) in the form of low-income apartment blocks for workers in the Cairo suburbs of Helwan and Shubra. State-planned residential areas were laid out along class lines, with middle class suburbs designed for the professional elites forming the social base of the new regime. ${ }^{40}$ In the new working class areas, traditional layers of control and mediation disappeared, and in their place there emerged a system of surveillance centred around police stations-control of workers

36 Ibid.; see also Diane Singerman, Avenues of Participation: Family, Politics and Networks in Urban Quarters of Cairo (New Jersey: Princeton University Press, 1995), and Arlene Elow MacLeod, Accommodating Protest: Working Women, the New Veiling and Change in Cairo (New York: Columbia University Press, 1991).

37 Al-Messiri-Nadim, "The Concept of the Hara."

38 Georg Stauth, "Gamaliyya: Informal Economy and Social Life in a Popular Quarter of Cairo," in Informal Sector in Egypt, ed. Nicholas Hopkins, Cairo Papers in the Social Sciences (Winter 1991), 78-103.

39 Ibid.

40 The development of neighbourhood along class lines extends back to the turn of the century, see Robert Ilbert, "Égypte 1900, Habitat populaire, société coloniale," in État, ville et mouvements sociaux au Maghreb et au Moyen-Orient, eds., Kenneth Brown et al. (Paris: L'Harmmattan, 1989), 266-82. 
was a preoccupation of the regime. ${ }^{41}$ These areas have been the sites of workers' protest, erupting from factories and perhaps drawing on the surrounding housing areas where family and kin reside. The industrial zones, though originally planned by the state, have also become sites for informal housing communities. Since the 1960s, this type of community began to spread to the outskirts of the city, and, today, such areas house one third of Cairo's population and have emerged as the new popular quarters. It is to these communities that I now turn.

\section{THE NEW POPULAR QUARTERS AND THE ISLAMIST}

\section{OPPOSITIONAL MOVEMENTS}

Before proceeding to an examination of the key features of contemporary urban social organisation, I would like to note the particularities of the Islamist presence in the urban setting. An investigation into the areas where Islamist activism and confrontation with the government has occurred reveals a concentration in popular neighbourhoods and quarters - namely, those areas which have emerged "spontaneously" and have come to be known as informal housing communities. These have mainly developed on the periphery of greater Cairo (Cairo, Giza and Qalyubiya) as well as in nine other Egyptian governorates. Islamist implantation in these areas is discussed in greater detail below. At this point, however, we should map the evolution of this presence over the last two decades.

The importance of spatial determinants is indicated by al-Takfir wa alHijra's group strategy of separation by segregation in the peripheral areas of southern Cairo. The group's flight from the inner city was ideologically justified in terms of hijra, modelled after the migration of the Prophet from Mecca to Medina. This tenet was not espoused by the Jihad group, but many of its members lived and operated in peripheral areas such as Boulaq al-Dakrur, Matariya and Sahil, forming cells headed by emirs, as in the Nahya district of Imbaba. ${ }^{42}$ In fact, the places of residence in the early 1990s of members of the new military section of the reconstituted Jihad (known as Talai ${ }^{c}$ al-Fatih or Vanguard of Conquest) confirm a particular pattern of spatial distribution. This pattern also crystallised in other groups from the mid-1980s on. First, we find new groups emerging in these spaces, notably al-Najun min al-Nar (Escapees

\footnotetext{
41 For an overview of state urban planning policies see Galila al-Kadi, "Trente ans de plannification urbaine au Caire,” Revue Tiers Monde 31, 121 (Janvier-Mars 1990): 185-207.

42 Based on files from the Jihad trial, Case 462, 1981. See the summaries of the interrogation statements of the accused Jihad members in Ni mat Gueineina, Tanzim al-Jihad: Hal Huwa al-Badil al-Islami fi Misr [The Jihad Organisation: Is it the Islamic Alternative in Egypt?] (Cairo: Dar alHurriya, 1988). In his study of the Jihad group, Gilles Kepel partially attributes this spatial distribution to the movements of the group's leader around the city. See The Prophet and the Pharaoh: Muslim Extremism in Egypt (London: Al-Saqi, 1985).
} 
from Hell), and al-Samawiya (named after its leader Taha al-Samawi), whose members resided in Boulaq, Matariya, and Imbaba. Then, a clear case of territorialisation develops, with full-fledged efforts at appropriating the peripheral spaces. The informal housing communities, therefore, served not only as places of residence and hiding, but also as areas of militant concentration and activity. ${ }^{43}$

We should now turn to the new urban popular quarters and examine their spatial features and socioeconomic configuration. This is necessary in order to shed light on contemporary Islamism as a form of contestation shaped by the setting in which it operates.

The establishment of informal housing settlements and the practice of squatting on public land in Cairo are not, in themselves, new phenomena. ${ }^{44}$ However, the large-scale development of informal housing communities is a more recent occurrence, dating from the mid-1960s. In simple terms, these communities arose in response to the increased popular need for urban housing and the state's failure to meet that need. ${ }^{45}$ Population growth, dislocation and resettlement and rural-urban migration were all factors contributing to urban expansion. State urban housing and planning did not keep up with this expansion. The state began providing fewer subsidised rental units in the mid 1960s, and by the early 1970s had moved into the production of medium-cost and luxury flats for private ownership. As a result, responsibility for much urban management and housing provision was assumed by the people themselves. In Cairo, this translated into the appropriation of public land and illegal construction on agricultural land. The process of informal housing development has, thus far, resulted in the emergence of seventy-four informal settlements in twelve areas of the

43 My evidence of the Islamist presence in these areas is based on reports of state security operations there, arrest records indicating the militants' place of residence, and documented activism. State security operations are carried out with the aim of finding the hideouts of escaped militant defendants and the locations of weapons caches. The Egyptian press regularly reports on police campaigns which, in many cases, result in shootouts and casualties. Among these, it is worth mentioning the early 1994 attacks on hideouts in Ma'sara and al-Zawiya al-Hamra, which resulted in the death of seven Islamists in a flat in al-Zawiya al-Hamra. Annual compilation of data on these events may be found in al-Taqrir al-Istratiji al-Arabi [The Arab Strategic Report] (Cairo: al-Ahram Center for Strategic Studies). In 1990, ten security operations were conducted in Ain Shams, Imbaba, Helwan, and Umraniya. The number of operations increased to fifty in 1993, taking place in Imbaba, Boulaq, Haram, Ain Shams, Matariya, Shubra, and Zaynhum. Galal Abdallah Mu'awad, alHamishiyun al-Hadariyun wa al-Tanmiya fi Misr [The Urban Marginals and Development in Egypt] (Cairo: Cairo University, Faculty of Economics and Political Science, 1998). Other communities that did not have strong militant formations witnessed the implantation of organised Islamic voluntary organisations, such as al- ${ }^{\mathrm{C}}$ Ashira al-Muhammadiya in Manshiyat Nasir.

44 For antecedents of squatter-type settlements in Cairo and Alexandria, see Robert Ilbert, "Égypte 1900." Ilbert views the 'ishash (huts) development at the turn-of-the-century as an expression of the same phenomenon. At the base, urban planning policies were directed in the interests of the society's dominant forces.

45 On state housing policies, see Milad Hanna, al-Iskan wa al-Masyada [Housing and the Trap] (Cairo: Dar al-Mustaqbal al-Arabi, 1988). 
city. ${ }^{46}$ The housing in these areas ranges from temporary shelter made of tin huts and shacks to permanent structures several stories high. ${ }^{47}$

Informal housing communities have developed as spaces of urban contestation and have come to represent an important arena of Islamist activism. The anchoring of Islamist groups in these communities must be understood in terms of the physical characteristics of the spaces and the forms of social organisation which are inscribed in them. In spatial terms, these communities exist on the periphery of the city and are not easily accessible - given that their rise was not part of state planning, they cannot be accessed via paved roads and have no means of public transportation. Some are also rather forbidding to outsiders, due to a rocky landscape or otherwise inhospitable environment. As the maximisation of housing space is a valued objective in the development of these communities, streets tend to be narrow with little public space and buildings running back to back and side by side for kilometres, as is the case of Munira in Imbaba. ${ }^{48}$ The high population density makes control and surveillance difficult. The narrow streets, unpaved roads, and labyrinthian layout render the areas uncharted territory for outsiders, including the state authority. In fact, until recently, the agents of state control—particularly the police-were absent from most of these spaces.

As communal efforts undertaken to resolve the housing problem, the informal communities have arisen in violation of government rules and regulations concerning construction. This process of development has given the communities a certain degree of autonomy from the government - the latter having been completely absent during the communities' founding stages of planning and construction. Unable and unwilling to meet popular housing needs, the state turned a blind eye to the informal housing communities.

Community solidarity and forms of collective action have developed through the process of implantation. Forms of social organisation and community control differ according to the history of development-whether communal or managed by contractors. Where squatting on public land was collective and in defiance of the state, the communities have organised along lines such as kinship, place of origin, and date or period of arrival. As a consequence, in places like Izbat al-Haganna in Madinat Nasr, Manshiyat Nasir in the Muqattam and Istabl Antar in Fustat Hill, a power hierarchy has emerged with modes of control based on these various lines of social differentiation. This pattern is less

46 This discussion of the informal housing communities draws on Salwa Ismail, "The Politics of Space in Urban Cairo: Informal Communities and the State," Arab Studies Journal 4, 2 (Fall 1996): 119-32.

${ }^{47}$ For a comprehensive map of the informal housing communities in Egypt see Mamduh alWali, Sukkan al-Ishash wa al-Ashwa'iyat: al-Kharita al-Iskaniya lil-Muhafazat [The Inhabitants of Huts and Haphazard Communities: A Map of the Governorates] (Cairo: Engineers Syndicate, 1993).

${ }^{48}$ Linda Oldham, Haguer al-Hadidi and Hussein Tamaa, "Informal Communities in Cairo: The Basis of a Typology," Cairo Papers in the Social Sciences 10, 4 (Winter 1987). 
likely to develop where contractors control the process of implantation, dividing the plots and putting up illegal private construction. This latter type of division is found in Munira al-Gharabiya in Imbaba. However, even in Imbaba a communal type of implantation has taken place in sections such as Izbat al$\mathrm{Sa}^{\mathrm{c}}$ yada, whose inhabitants migrated from Upper Egypt following the initial settlement of a single individual and his family.

Studies of the informal housing communities reveal a mode of action and relationship to government which reflect activism and initiative. ${ }^{49}$ The residents pursue strategies of engagement and disengagement with the government depending on their needs, employing tactics which bring about either visibility or invisibility, to suit their situation. Residents of the communities organise and engage in collective action to pressure the government to provide services, confer legal status on them, and acknowledge their legitimate right to continue to live in the spaces they have appropriated. In other instances, the residents choose to meet their needs through private means, by collectively investing in the provision of services: purchasing cables and transformers for the connection of water and electricity, paying for sewage tanks and the removal of solid waste.

The social groups residing in informal housing communities make up the expanded popular classes. These are the social forces that developed with the growth of commercial and service sectors of the economy under the policies of infitah (open door) and privatisation, and with the accompanying restructuring of the labour force. 50 "Popular" is defined in opposition to the dominant forces - the political and economic elites. It also refers to the economic and social position of a number of classes or fractions of classes which, because of the blurring of boundaries, are not easily distinguishable. The fluidity and blurring of lines has to do with occupational mobility and the fact that members of these classes hold more than one job simultaneously. A common feature between them, however, is the predominance of informal economic activities. This applies to the artisans, petty traders, low-level service sector workers, construction workers, and craftsmen. Many of these workers are grouped under the category of hirafiyyin (craftsmen or tradesmen). Levels of skill vary and so do positions within the craft, from the self-employed and workshop owners, to contractual workers, to daily workers. Informal economic activity signals a change both in the structure of work and the social organisation which accompanied the move to new quarters.

Before proceeding to discuss other characteristics of the popular classes, it is important to reflect on the working classes' position as one of their constitu-

49 These studies are discussed in Ismail, "The Politics of Space." The main insights in my understanding of the dynamics of community organisation are drawn from Agnes DeBoulet, "État, squatters et maitrise de l'espace," Égypte/Monde Arabe 1 (1er trimèstre 1990): 79-96; Oldham et al., "Informal Communities."

50 See Nader Fergany, "A Characterisation of the Employment Problem in Egypt," in Employment and Structural Adjustment in Egypt in the 1990s, eds. Heba Handoussa and Gillian Potter (Cairo: The American University in Cairo Press, 1991), 25-56. 
tive components. In looking at the Egyptian setting we find that there is a need to nuance the terms of this inclusion. First, the construction of masakin sha biya (popular housing) in housing areas designated for state workers allowed for working class concentration in distinct districts and neighbourhoods of the city. Second, the patterns of working class activism are inscribed within state corporatist structures which were put in place by the Nasser regime after the 1952 revolution. Thus, working class forms of contestation are framed by terms of negotiation and exchange that have been worked out with state-controlled unions. These factors have served to distinguish the working class in terms of residential distribution, relations with the government, and everyday forms of social organisation. I will come back to the question of the apparent absence of Islamist mobilisation among the working class.

There is a residential aspect to the identification of the popular classes. Until recently, the category referred to residents of the old quarters. It would seem appropriate now to include the new neighbourhoods. The latter are distinguished in a number of ways. They are mainly inhabited by young "nuclear families" that have come from the villages or have moved from the old quarters, leaving their extended families behind. The physical characteristics of the new neighbourhoods are different from the old, but, as Singerman points out, the popular classes "take the hara culture with them." 51 Thus, the popular classes are also distinguishable from other social strata in cultural terms. This has to do with the people's claim to authenticity. Values, norms, and practices associated with the popular classes are seen as true and authentic and opposed to the "fake" values and lifestyles of the upper classes. The socio-spatial factors outlined so far are important to the constitution of the popular classes as a political force.

A study of Manshiyat Nasir shows the predominance of trades work among the residents. Most of these tradespeople work in the informal sector. ${ }^{52}$ This type of work composition is also reported in a study of Izbat al-Hagana. ${ }^{53}$ A report commissioned by the governorate of Giza lists fifty percent of the residents of informal communities as peddlers, daily workers and craftsmen. ${ }^{54}$ In the current socioeconomic juncture of economic liberalisation and privatisation, the employment ranks of the informal sector are expanding, due to the convergence

51 Singerman, "Avenues of Participation," 22.

52 Belgin Tekçe, Linda Oldham and Frederic Shorter, A Place to Live: Families and Child Health in a Cairo Neighborhood (Cairo: The American University in Cairo Press, 1994).

53 Duha Al-Maghazi, "Sukan al- 'Ashwa'iyat bayna Thaqafat al-Faqr wa Istratijiyat al-Baqa, Dirasat Anthropologiya," [The Residents of Haphazard Communities between the Culture of Poverty and the Strategies of Survival: An Anthropological Study], in Proceeding of the Conference on al-Mujtma al-Misri fi Daw Mutaghayrat al-Nizam al- ${ }^{c}$ Alami [Egyptian Society in Light of the Changes in the International System], eds. Ahmad Zayid and Samiya al-Khashab (Cairo: Cairo University, Faculty of Arts, 1995).

54 The results of the report are published in al-Ahali, 1 May 1994. 
of different types of entrants. On one hand, we find individuals with lower levels of education and limited skills and, on the other, university graduates. In fact, Hoodfar's study of households in one of the new neighbourhoods shows that, increasingly, young males are leaving school at an early age to learn a craft. This represents a family-based response to changes in the job market, whereby a higher education neither improves job opportunities nor brings higher income. ${ }^{55}$ A similar pattern is revealed in a 1989 study of Munira al-Gharbiya in Imbaba, showing a high rate of illiteracy among children over ten years old (forty-nine percent). The study reports that twenty-one percent of children under the age of fifteen have entered the labour force and that thirty-five percent of the total number of children in the households surveyed are engaged in crafttype employment. ${ }^{56}$ The entry into the artisan/tradesworker class by the educated segments of society is another development. Many of today's construction sector workers, such as house painters, plasterers, and tile layers, are university graduates with engineering and law degrees. Indeed, these degreeholders find themselves among the group of arzuqi workers (daily job-seekers) who bide their time in coffee shop cum labour markets, waiting for employment. ${ }^{57}$

Networks based on kinship and regional origin are avenues of entry into the job market for the residents of the informal housing areas. In Manshiya Nasir, individual kin groups enjoy links to particular trades. Thus, those originating from the Araba, in the Upper Egypt province of Sohag, have better access to the building trades and to such jobs as house painting and plastering. ${ }^{58}$ In Manshiya, the residents supply twenty percent of the labour force employed in the workshops and stores of the area. ${ }^{59}$ The social networks of the Manshiyat residents extend beyond the place of origin and the borders of the community to include other quarters of the city. In fact, Tekçe, Oldham and Shorter contend that "the patterns of interaction are becoming similar to those of the older urban neighbourhoods." 60 In her study of Izbat al-Hagana in Madinat Nasr, alMaghazi confirms the importance of familial and neighbourhood networks to the social interaction and economic activity of the residents, many of whom establish workshops or small stores in the community. The informal labour

55 Homa Hoodfar, "Survival Strategies and the Political Economy of Low-Income Households in Cairo," in Development, Change and Gender in Cairo: A View from the Household, eds. Diane Singerman and Homa Hoodfar (Bloomington: Indianna University Press, 1996), 1-26.

56 Iqbal al-Amir al-Samaluti, "Nahwa Namudhaj Tanmawi li Muwajahat Ihityajat alMujtama ${ }^{c}$ at al-Hadariya al-Mutakhalifa bi al-Tatbiq al-Mujtam ${ }^{c}$ al-Munira al-Gharbiya [Towards a Developmental Model for Meeting the Needs of Underdeveloped Urban Societies with Application to the Society of Munira al-Gharbiya], cited in al-Wali, Sukkan al-Ishash, 79.

57 The presence of university graduates in these markets was brought to my attention by Diya' Rashwan. On the informal labour market see Ragui Assaad, "Formal and Informal Institutions in the Labor Market, With Applications to the Construction Sector in Egypt," World Development 21, 6 (1993): 925-39.

58 Tekçe et al. A Place to Live. $\quad{ }^{59}$ Ibid. 60 Ibid., 55. 
market is, in many ways, self-regulating. Its structures and regulatory institutions operate in a manner similar to the guild system, with rules of entry, apprenticeship and forms of solidarity and sociality which are now centred on coffee shops rather than workshops. ${ }^{61}$

The commercial life of the neighbourhoods revolves around the market running through the main thoroughfare, where shops and kiosks are located. There is little space for cars to pass through. Informality is once again the predominant character of these markets. However, they have their shaykhs, who act as mediators with government, or organise the trade of particular goods. ${ }^{62}$ The informal markets are also sites of confrontation with the police, whenever this latter tries, from time to time, to impose "law and order."

The above composite portrait of informal housing communities highlights the characteristics of the new popular neighbourhoods. This is a first step towards integrating them into the analysis of contemporary social and political activism in Egypt (the informal communities have been the subject of anthropological and sociological studies, but there has been little attempt to incorporate them into political studies). On one hand, the informal housing communities appear to represent marginality and invisibility, and have thus been officially discounted. The common term used to designate them is ashwa iyat (haphazard), which stresses the absence of planning and organisation and their lack of integration into the wider community. However, this characterisation is belied by the few available studies. In terms of organisation and spatial arrangements, the communities actually tend to show a degree of planning, and a utilitarian approach to the space.

As for their relationship to the state, we can find dynamics of both engagement and disengagement. It is their positioning in relation to the wider society which is more complex. As noted, these communities tend to exist in relative separation, as a result of the physical characteristics of the space and their lack of integration into the main municipal road system. However, in their pursuit of a living, the residents have established familial and market-linked networks which extend beyond their communities. In this, they are not very different from the old popular quarters. In fact, many of the residents of the old quarters have moved to informal housing areas. Some were even at the forefront of the original establishment of informal communities, after their former homes collapsed or had to be evacuated. ${ }^{63}$ According to Eric Denis, these neighbourhoods

61 This is confirmed by Assaad in his studies of the informal labour market in the construction sector and of the garbage collectors. Assaad, "Formal and Informal," and "L'Informel structuré: Les Zabalin du Caire," Peuples méditerranéens 41-42 (1988): 181-92.

62 On the organisation of squatter markets see Helmi R. Tadros, Mohamed Fateeh and Allen Hibbard, "Informal Markets in Cairo," Cairo Social Sciences Papers 13, 1 (1990). See also Mustafa Kharoufi "Du petit au grand espace urbain: Le commerce des fruits et légumes à Dar al-Salam," Égypte/Monde Arabe 5 (1er trimèstre 1991): 81-96.

63 It is estimated that by 1986 , five hundred thousand residents of the old quarters had relocated, many moving to informal housing communities. Eric Denis, "Urban Planning and Growth in Cairo," Middle East Report 27, 1 (Winter 1997): 7-12. 
are "veritable cities, popular districts with commerce, markets, and a multitude of private services that make up for the absence of the state and its schools, clinics and bus lines. It is here that one now finds the people of Cairo." 64

The conventional view is that the popular classes are apathetic, and that if they engage in action, it is only as a result of their social frustration or the manipulation of their religiosity. Yet a closer look at the strategies of community development and consolidation pursued by these classes tells a different story. In strategies of engagement and disengagement, they developed practices which challenge state authority. Through community organisation and the establishment of informal networks, the groundwork for autonomy was laid. Part of my contention is that Islamist activism should be placed within a broader social context, which takes account of the different forms of social and spatial organisation that have come about with the socio-economic changes of the current juncture. Islamism is not a marginal religious or political movement or merely a militant ideology with few adherents. Rather, it is a form of contestation that finds ground in spaces where oppositional positioning develops. André Raymond has observed that while popular quarters and classes seem to erupt onto the scene in historical periods of crises, the conditions for such eruption are rooted in modes of social and territorial organisation. This observation has relevance to the contemporary context. Indeed, militant Islamism should not be viewed as the activism of a marginal and alienated group, but rather through the prism of the social geography and the urban landscape in which it has taken root. The Islamists anchor themselves in oppositional spaces already formed or in the process of formation. The terms of this opposition are spatial, social, cultural, economic, and political. As noted by Denis, these neighbourhoods "propose a reformulation of the popular city, recovering the social role of the street." 65 The dynamics of Islamist insertion into this setting and the logic of their action are factors which influence their ability to direct popular activism and its eruption onto the urban scene.

\section{ISLAMIST IMPLANTATION IN THE NEW POPULAR QUARTERS}

As noted above, the presence of militant Islamist groups in peripheral areas of the city dates to the early period of activism in the 1970s. However, a crystallisation took place in the 1980s. An important factor in the consolidation of Islamists within the informal housing communities was al-Jama ${ }^{c}$ a al-Islamiya's decision to migrate to Cairo from Upper Egypt, in response to increased pressures from the state security services and confrontations with the police. Their destination, in most cases, was the informal housing areas. Ain Shams and Imbaba were favoured because of their characteristics, as noted above: peripheral location and a degree of invisibility. Ain Shams is located on the north-

64 Ibid., 10. 65 Ibid. 
eastern edge of Cairo. Imbaba is situated in north Giza, falling within the boundaries of greater Cairo. These two areas are not necessarily peripheral in terms of their geographical distance from the centre, but in terms of their lack of integration into the main road and transport systems and the social services network. For example, as late as 1993, Munira in Imbaba was accessed by an informal network of unlicensed vans. Its main thoroughfare was unpaved and visitors had to negotiate their way over old railroad tracks and barbed wire in order to enter the area. In the late 1980s, Ain Shams had only two paved roads.

Imbaba was originally an agricultural urban fringe which, under the industrialisation policies of President Nasser, saw the establishment of factories accompanied by some popular housing construction. Migrants to the city flocked to the area, where contractors put up cheap housing units. This early association with an industrial base accounted for the spread of socialist ideas and activism in the 1960s and 70s. The area's potential as a locus of protest is borne out by the fact that it was one of the first places where the bread riots broke out in 1977.66

The Jama a found in these spaces an appropriate territory for mobilisation and action. Their organised implantation in Imbaba began in the mid-1980s, when a small cell under the direction of Rifa ${ }^{c} i$ Ahmad Taha, a leading member now residing outside Egypt, met with a number of residents and formed the group's nucleus. This nucleus was composed of young migrants of Upper Egypt origin. ${ }^{67}$ Through religious education, they managed to recruit more youths. An aspect of the Jama 'a's attraction was its confrontational stand vis-à-vis the government, a stand which distinguishes it from the Muslim Brotherhood (MB). According to a leading member, the youths rejected the MB's soft position. Here we have a clue to the youths' preference. ${ }^{68}$ Occupying a position of conflict and confrontation with the state was more appealing. It was not the religious ideas per se that were at issue, but the practical conclusions drawn from them, more specifically the positions of resistance they made available.

As part of this organisation, the Jama ${ }^{c}$ a sent a speaker and representative to Imbaba, and divided the area into ten main sections, positioning emirs in the main streets and alleys and in the mosques. ${ }^{69}$ Following conventional Jama a strategy, new recruits were given religious education in mosques or zawiya (a small mosque or prayer room); the lessons were given by the local emir and outsiders were easily identified. ${ }^{70}$ The Jama ${ }^{c}$ a controlled five mosques in the main streets of Munira, giving them access to many of the worshipers. The mosques were sites from which they could control the main streets, as well. As

66 Hisham Mubarak, al-Irhabiyun Qadimun: Dirasa Muqarana Bayna Mawqif al-Ikhwan alMuslimin wa Jama a at al-Jihad min Qadiyat al-'Unf, 1938-1994 [The Terrorists are Coming: A Comparative Study of the Position of the Muslim Brotherhood and the Jihad Groups from the Question of Violence 1938-1994] (Cairo: Dar al-Mahrusa, 1995).

67 Ibid., 246. 68 Ibid. 69 Ibid., $247 .{ }^{70}$ Ibid., 248 
part of their ideological and political consolidation, the Jama ${ }^{c}$ a used videocassettes, journals, and weekly popular meetings to disseminate their views. For instance, it has been reported that at least one of these meetings attracted six hundred attendees. ${ }^{71}$ Gatherings spilled over into the street, and thus were visible to non-participating residents. The weekly speeches were broadcast over microphones and heard beyond the vicinity of the mosque and the main street. The Jama ${ }^{c}$ a succeeded in attaining a visible presence where the state and its agents were absent.

Moreover, the group provided social services through a "social work committee." The committee helped poor residents with health care and education, setting up projects that included support for orphaned students, and the distribution of books and food. ${ }^{72}$ Money was raised from merchants in the market, a practice which was classified as zakat (alms collection) by the group, but as itawat (protection money) by its opponents. In addition, the Jama ${ }^{c}$ a was active in the area of social relations, enforcing social mores and regulating gender relations. In resolving disputes among the residents, the emir bypassed the traditional tribal council, whose powers were waning in the face of spreading anomie and drug abuse. ${ }^{73}$

A similar mode of implantation took place in Ain Shams, where Jama ${ }^{c}$ a members exercised wide-ranging powers over some of the districts and neighbourhoods (e.g., Alf Maskan, al-Zahra and Masakin Ain Shams). There are some indications that this implantation involved modes of planning parallel to those undertaken in Imbaba. For example, directives were given to place Safwat Abd al-Ghani, a Jama ' a military strategist and a prominent figure of the Jihadist current, in the Adam mosque. ${ }^{74}$ Another important figure, Hasan al-Gharabawi, was relocated there by the Shura Council in Asyut. Al-Jama ${ }^{c}$ a controlled a number of mosques, namely Adam, Fatima al-Zahra' and al-Anwar alMuhammadiya. Weekly seminars were held in the Adam mosque. Jama ${ }^{c}$ a members exacted donations from the merchants in the Ibrahim Abd al-Raziq market, where they were actively propagating their ideas. These funds were used to finance the social work committee which operated from the mosque. In addition to preaching and providing social services, the Jama ${ }^{c}$ a attended to matters of social mores - forbidding mixing between the sexes, banning music, and monitoring entry into the area. It enforced the rules and applied the hudud (religious ordinances).

In each of the above cases, the group came into conflict with the state. The immediate causes for this confrontation differ, and reports tend to conflict. However, it was official cognisance of the growing Islamist challenge which brought the state to act. The police took action in Ain Shams in 1988. It penetrated the area by force, cleared the market and set up roadblocks in the streets

71 Ibid., 256. 72 Ibid., 262. 73 Oldham et al., "Informal Communities".

74 Al-Ahali, 1 September 1993, 10. 
and alleys, as well as checkpoints at the main entrances to some of the neighbourhoods. Demonstrations ensued and people marched on two police stations and set them on fire. They also burned police security cars. Islamists and their supporters blockaded themselves in the mosque and were besieged by the police. The clashes lasted four days, ending with hundreds of arrests. The government was again moved to act in 1992, in the face of local and international media reports claiming that Imbaba had fallen under Islamist control. Thousands of police personnel were brought in to "recapture" the territory. The clashes lasted for three weeks. Following this incident, the government intensified the politics of security, opening access roads to the area and lighting the streets. It also embarked on a project of upgrading for some areas and planned removal for others. The implementation of the new policies has been gradual, and it is too early to determine the outcome.

THE POPULAR MOVEMENT DIMENSIONS OF CONTEMPORARY MILITANT ISLAMISM

Earlier studies of the first militant groups elaborated an ideal type of the Islamist militant: a university student or young graduate, usually in one of the engineering or medical faculties, and of rural origin. According to Saad Eddine Ibrahim's work on the 1970s generation of Islamists, the typical militant was a high achiever. More recently, Ibrahim has found that the "ailment" of the high achiever has spread to "younger and less educated Egyptians."75 Alienation, deprivation, and discontent are components of what he terms the "inner sociological logic" of Islamist activism. As noted above, however, it is more helpful to approach militant Islamism in terms of its social rootedness, rather than in terms of uprootedness. This requires a more differentiated account of the ties that bind the militants to their social context. I will turn to this account below.

Increasingly, the militants include artisans or hiraffiyin (tradespeople). This is confirmed by data drawn from police case files pertaining to a 1986 investigation of some members of al-Najun min al-Nar and al-Samawiya, to the arrests made in the Ain Shams events in 1988, and to those members of the new Jihad-Talai $^{c}$ al-Fatih group who were brought up on charges in 1993. The occupational profile of the Samawiya group, based on the list of seventy-six accused and brought to trial, is as follows: twenty-nine technical workers in the service industry (including three owners of workshops); eleven students in vocational training schools and high schools; three cab drivers; two traders; two mosque keepers; one farmer; a popular singer; twelve university graduates (of whom three were teachers, two engineers, one doctor, and the remaining six in accountancy and clerical jobs); six university students; three enlisted in the army, for whom no educational background was specified. The occupations of

75 Ibrahim, "The Changing Face,” 36 
six others were not indicated. ${ }^{76}$ For al-Najun min al-Nar, the list of thirty-three accused are grouped into the following occupational categories: sixteen professionals; ten craftsmen; two traders; two unemployed; one student; two unknown. ${ }^{77}$ The list of the accused in the Ain Shams events shows a very similar breakdown. ${ }^{78}$ Among the first group of Talai al-Fatih members to be arrested, totalling fifty-two individuals, a similar pattern emerged, with many having vocational training and working in trades, particularly housepainting and petty trading. There were also some students among their number. ${ }^{79}$

In terms of age composition, this new generation of Islamists maintains the youthfulness of its predecessor. Looking at the age breakdown of the members in the cases examined above, it is found that seventy-five percent of activists were below the age of thirty and that only twenty-five percent are thirty or above. ${ }^{80}$ Data regarding the marital status of activists is sketchy. The question raised here is whether militancy is more prevalent among a particular group, namely single young men with little familial responsibilities and more mobility. The predominance of younger members would confirm the association of activism and youth. ${ }^{81}$ However, it should be noted that a number of the emirs were married and had children, and that the wives were engaged in support activities, such as hiding weapons. There is a degree of intermarriage among group members. Activists arrange for their sisters to marry fellow members, thus forging a bond as brothers-in-law. Sisters also introduce female friends to their brothers as suitable marriage partners. ${ }^{82}$ Membership in the Jama ${ }^{c}$ a is viewed as a means of securing a partner and gaining financial support for the marriage. At the same time, established marriage links aim to solidify the relationships among group members.

As noted earlier, the apparent absence of Islamist mobilisation among the working class $\left(\mathrm{al}-{ }^{\mathrm{C}} \mathrm{umal}\right)$ can be explained in terms of the form of incorporation that has characterised the latter's relation to the state in the post-revolution period. Within the state corporatist arrangements framing the workers' activism, protest became focused on sit-ins and strikes, which usually ended in negotiated

76 Al-Gumhuriya, 2 September 1988, and al-Ahram, 2 September 1988.

77 Al-Ahrar, 16 November 1987. ${ }^{78}$ Al-Ahram, 23 April 1989.

79 Al-Gumhuriya, 12 August 1993.

80 This concurs with Hisham Mubarak's age breakdown for the groups he studied.

81 As pointed out by Gregory Starrett, young men in particular enjoy opportunities to experience diverse ideological and cultural views in coffee shops, mosques, schools, and so on. These opportunities allow them to escape the tight social controls imposed within the family. Gregory Starrett, Putting Islam to Work: Education, Politics and Religious Transformation in Egypt (Los Angeles: University of California Press, 1998), 170.

82 In one militant cell, the emir, Adel Siyam, married Hayam Abd al-Alim, sister of Ahmad and Muhammad Abd al-Alim, two male activists. It was Hayam's brother Muhammad who arranged the marriage. Muhammad's own marriage to Huriya Abd al-Satar was arranged by his other sister, Amal. Al-Ahram, 18 June 1994. 
settlements. ${ }^{83}$ Workers' demonstrations have taken place around the areas of work and, again, the unions have acted as intermediaries to avoid long drawn out standoffs. The established working class's oppositional tactics have intensified in the 1990s in response to liberalisation and privatisation policies. ${ }^{84}$ The militant Islamist ideological discourse does not seem to address itself to this situation. However, we cannot generalise that there are no workers among the Islamists, nor that there is an inherent animosity between the working class and Islamist activists. It should be recalled that the Muslim Brotherhood was active in working class areas in the late 1930s, and by the mid-1940s, it carried out an organisational campaign among the workers of Shubra al-Khayma. ${ }^{85}$ The ideological principles of the Brotherhood, which were framed in moral and cultural terms, had their appeal under conditions of colonialism and the foreign ownership of industries. However, these principles became less salient with the Egyptianisation of industry and the subsequent move to "corporatist nationalism" in the 1950s. ${ }^{86}$ At the ideological level, the discourse of today's militants suffers similar limitations on its ability to appeal to the workers. Nonetheless, there are cases of militant Islamist activism among the workers in some of the industrial areas of Upper Egypt, namely Naj ${ }^{c}$ Hamadi and Dishna. ${ }^{87}$

Militant Islamist operations carried out in Cairo in the 1990s were directed internally by hirafiyyin: emirs in many of the areas were also tradesmen. Among the emirs of the Jama ${ }^{c}$ a, we find an electrician (Shaykh Jabir of the Imbaba group), and a law student/poultry merchant (Gharabawi of Ain Shams). In addition, tradesmen were the targets of religious lessons held in militant-run mosques in the popular neighbourhoods of Alexandria. ${ }^{88}$ In sum, those making up this social force tend to have a high school level technical education, be engaged in petty trade, and employed in a wide range of jobs in the service and construction industries: as mechanics, house painters, plumbers, and carpenters. ${ }^{89}$ Members of some of the Islamist groups tend to reject government em-

83 Marsha Pripstein Posusney qualifies the Egyptian workers' activism as "defensive and restorative." See her "Collective Action and Workers' Consciousness in Contemporary Egypt," in Workers and Working classes in the Middle East: Struggles, Histories, Historiographies, ed. Zackary Lockman (New York: State University of New York Press, 1994), 211-46.

${ }^{84}$ For a chronicle of labour protests in the 1990s see the annual publication of al-Taqrir alIstratiji al-Arabi.

85 See Joel Beinin, "Islam, Marxism, and the Shubra al-Khayma Textile Workers: Muslim Brothers and Communists in the Egyptian Trade Union Movement," in Islam, Politics, and Social Movements, eds. Edmund Burke, III, and Ira M. Lapidus (Los Angeles: University of California Press, 1988), 207-27.

${ }^{86}$ Ellis Goldberg, "Muslim Union Politics in Egypt: Two Cases," in Islam, Politics, and Social Movements, eds. Edmund Burke, III, and Ira M. Lapidus (Los Angeles: University of California Press, 1988), 228-43.

87 Personal communication with Diya' Rashwan.

88 Ruz al-Ysuf, 30 May 1994.

89 Based on a compilation from seven court-cases involving militants between 1991 and 1993 and a larger number of accused, Hisham Mubarak provided a different occupational profile. His occupational distribution puts the total percentage of professionals at 26.2 percent, students 25 
ployment on a matter of principle, in favour of self-employment. They set up businesses and establish job networks as part of their strategies. ${ }^{90}$ Hence, their responses are not different from others in the popular classes, who recognise that there are no jobs to be had in the government.

Most of these newly-created jobs are held in the informal economy. In urban areas, informal jobs and informal housing go together. More than half of the workers in the informal sector live in informal housing communities, especially Ain Shams, Imbaba, Boulaq, Matarya, and Haram.${ }^{91}$ Within this sector are found unregistered, small businesses which employ less than ten persons. Many of the jobs involve menial labour. In 1985, it was estimated that there were $2,887,000$ jobs in the informal sectors of production, commerce and services. ${ }^{92}$ In her study of a popular quarter in old Cairo, Singerman confirms the pervasiveness of informal economic activity, which constituted a primary source of income for thirty-eight percent of the economically active members of her sample, and a supplementary source of income for sixty percent. ${ }^{93}$ Further, production workers were heavily represented in this type of activity, most being hirafiyyin working in small manufacturing workshops. ${ }^{94}$ These informal economic activities depend on occupational and familial networks. Islamists are part of this socioeconomic configuration. The importance of informal networks as "avenues of participation" and quiet resistance has been demonstrated in recent studies, which note the activism in survival strategies and networks of reciprocity among the popular classes. ${ }^{95}$ To this picture should be added the open resistance and militant oppositional potential which contemporary Islamism can and does capture.

In occupational and residential terms, the Islamists are located among the popular classes in the new popular quarters. The views of the Jama a members in these areas are shaped by lessons in the zawiya and by popular religious education through cassettes and the sermons of popular preachers. They attend

percent, workers 21 percent, traders 3 percent, unemployed 20 percent, and 4 percent unknown. Although he argues that the ranks of university students have expanded and that this as an indication of the importance of the university, Mubarak does not indicate the fields of study or of professional training. Also, he does not specify the fields of economic activity for those listed as workers. The data for the four cases used here is more precise, and we know the types of trades the tradesmen are engaged in and the level and field of study of the students.

90 This may not be the case for the Jama ${ }^{c}$ a al-Islamiya, which sees in public sector employment a way of infiltrating the system or at least of finding employment for its members.

91 Mostafa Kharoufi, "The Informal Dimension of Urban Activity in Egypt: Some Recent Work," in Informal Sector in Egypt, ed. Nicholas Hopkins, Cairo Papers in the Social Sciences (Winter 1991), 8-20.

92 The figure is provided by Nader Fergany, and is quoted in Soad Kamil Rizq, "The Structure and Operation of the Informal Sector in Egypt," in Employment and Structural Adjustment: Egypt in the 1990s, eds. Heba Handoussa and G. Potter (Cairo: The American University Press, 1991), 167-85.

93 Singerman, Avenues of Participation, $178 . \quad 94$ Ibid., 187.

95 Ibid. 
weekly seminars that include religious speeches and updates on Jama 'a activities and news of Muslims in other countries. Thus, we witness a shift in terms of membership and location of recruitment and means of organisation. Islamist activism has moved from the university to the neighbourhood. However, the mosque and religious education remain central. ${ }^{96}$

In attempts to avoid police surveillance, residential flats have come to serve as new gathering-places. ${ }^{97}$ Direct access to followers is possible through the use of video-senders, whereby the Jama ${ }^{c} a$ is able to broadcast certain videotapes directly into the homes of members and sympathisers. ${ }^{98}$ To tune in, viewers are notified in advance of the transmission times of this alternative programming. In addition to juristic pamphlets, political newsletters and bulletins are now used. ${ }^{99}$ These analyse sociopolitical and economic conditions and deal directly with the people's difficulties, tackling issues such as increases in bread prices, government investment policies, and so on. Thus, "educational" activities pay greater attention to issues of daily concern, and address questions of exploitation and oppression. There has also been a marked shift in focus away from the problem of the infidel ruler to that of official corruption. ${ }^{100}$

My emphasis on occupational and residential factors aims to highlight the location of Islamism within a particular urban context, which shows the movement's popular dimensions. Thus, the analysis nuances earlier views which pointed to its elitist-vanguardist nature, evidenced in social background variables and the groups' approach to state and society. In both Ain Shams and Imbaba, the Islamists have engaged with the people. As noted above, they resolved disputes among neighbours, and provided social services and religious teaching. Many of the members come from families that know each other and are tied by kin relations. This provides the groups with familial, popular protection, which is vital to their capacity to confront and resist the authorities. Reports indicate that while committed members in Ain Shams numbered in the hundreds, the number of sympathisers who could be mobilised reached into the thousands. ${ }^{101}$

96 The assumption of the task of religious teaching by the lay emirs suggests an additional dynamic to the changes in the religious educational infrastructure examined by Gregory Starrett. Starrett argues that the modern religious educational system represents an important component of the infrastructural background of the "Islamic Trend." He contends that the functionalisation of religious education by the modern state has served to shift the bases of legitimate religious authority from the traditional centres of learning to the western-style school system. The new educated groups are thus able to appropriate claims to legitimate religious knowledge. As part of this structural transformation the need, and hence the market for religious information were created. From this perspective, the Islamisation of public life is part of the long-term change in the social relations of Islamic cultural production that accompanied the establishment of the modern educational system. See Starrett, Putting Islam to Work, 227-30.

97 See the responses of Tal ${ }^{c}$ at Qasim, the Jama 'a's public relations spokesperson, in interview with Hisham Mubarak, "Ba ${ }^{c} \mathrm{~d}$ Indhar al-Suyah wa al-Mustathmirin: al-Ahali Taltaqi fi al-Danmanrk bi al-Mutahadith al-I'lami li-al-Jama a at al-Islamiya" [After the Warning to Tourists and Investors: al-Ahali meets with the Jama'a's Public Relations Spokesperson in Denmark,] al-Ahali, 9 February 1994,3 .

98 Mubarak, al-Irhabiyun Qadimun. 99 Ibid. 100 Ibid.

101 Al-Mussawar, 15 December 1988. 
My exposé indicates that there have been significant transformations in the social makeup of the militants and in their engagement with society. However, elements of elitism or distance from society continue to exist in their ideology and practice. This may be attributed in part to the fact that the intellectual leadership seems to remain with the first generation or historic leadership and its disciples, ${ }^{102}$ many of whom are either in prison or residing abroad. A more important factor, which I have noted in my earlier work and which is consistent with the late Hisham Mubarak's assessment, is the ideological limitation of the Islamists' capacity to engage in popular action. Such constraints derive from the group's emphasis on the principle of al-amr bil ma ${ }^{c}$ ruf wa alnahy an al-munkar (enjoining good and forbidding evil). In some respects, the application of this principle recalls popular practices of social control and is thus acceptable. However, it also expresses an attitude of intolerance which contradicts popular norms of toleration and moderation. I will discuss this problem briefly.

Certain acts of violence carried out by the Islamists are directed against what they see as violations of public morality. Under the rubric of al-amr bil ma ruf wa al nahy an al-munkar, they commit acts of social violence directed against fellow citizens, including organised attacks on video clubs, cinemas and liquor stores. Other acts aim at enforcing an adherence to moral strictures usually relating to interaction between the sexes, the dress code and popular entertainment at weddings and during festive occasions. It is in these areas that the ambiguity lies. In challenging state and society, the Islamists often invoke popular traditions of male-dominated interaction between the sexes and family relations. Popular traditions thus serve as a frame of reference for contestation. As an oppositional strategy, this involves the merging of popular values with Islamic traditions. An example of such merging is the overlap of cayb (shame) and haram (illicit) in the popular imagination. 'Ayb is a principle of social control that is applied to many spheres and relationships, particularly family and gender relations, while haram is a principle stipulating religious restrictions. In practice, these principles fade into one another. The Islamists' concern with social mores in terms of halal and haram (licit and illicit) intertwines with the cayb tradition. ${ }^{103}$ Their ideas of gender segregation draw on horma (sanctity)

102 The main ideological texts are authored by this leadership. These include al-Farida alGha'iba by Abd al-Salam Farag, Hatmiya al-Muwajaha, and Mithaq al-Amal al-Islami, coauthored by the leaders of the Jama a in prison. There are also research pamphlets such as Falsafat al-Muwajaha by Tareq al-Zumur, and Research on Hakimiyya by Usama Qasim. Abd al-Fatah and Rashwan eds., Taqrir al-Hala 1995, 185. Some of these texts can be found in Muhammad Rif ${ }^{c}$ at Sayyid Ahmad, al-Nabi al-Musalah, al-Tha'irun (The Armed Prophet, The Rebellious) (London: Riad al-Rayyes Books, 1991).

${ }_{103}$ One should bear in mind that there is an ongoing process of cultural Islamisation which involves the state, the popular preachers, and the moderate Islamists. The merging of popular traditions and Islamic traditions is part of this process. See Salwa Ismail, "Religious 'Orthodoxy' as Public Morality: The State, Islamism and Cultural Politics in Egypt," Critique: Journal for Critical Studies of the Middle East 14 (Spring 1999): 25-47. 
regulations concerning the inviolability of women and the spaces with which women are conventionally associated. Historically, these regulations were enforced in the hara, which Islamist action, in the present, seeks to reinscribe in the new neighbourhoods. It should be noted that the housing conditions in some dwellings have served to undermine these regulations. The crowding of male and female family members in a single-room dwelling, and of whole families into shared accommodations transgresses the norms. Popular concerns with such issues have been expressed in questions directed to the Lajnat al-Fatwa (Religious Ruling Committee) of al-Azhar. ${ }^{104}$

Tahakum (arbitration to God) is a central idea in the Jihadist ideology and constitutes another area where the normatively grounded attitudes and practices of the quarter can be merged with Islamic principles. Past and present popular quarters have a tradition of arbitration, in which disputants turn to respected members of the neighbourhood as referees. The Jama ${ }^{c}$ a has stepped forward to occupy this role. Islamists have inscribed themselves in the space as mediators or agents of tahakum, to whom conflicting groups refer in order to sort out disagreements. ${ }^{105}$ The offices of the Jama ${ }^{c}$ a have reconciled disputing spouses, reinstated a son's financial obligations to his mother, settled outstanding debts, and so on. ${ }^{106}$ The intensity of the Jama a's involvement in social relations cannot be fully established from available data. However, what needs to be stressed is the symmetry between their modes of operation and popular avenues of social regulation in particular spheres. Here, the Jama ${ }^{c} a$ and the people converge in eschewing the involvement of public authority.

In a sense, the Jama a members occupy a multitude of roles, ranging from the futuwwa to the shaykh al-hara. Like the shaykh al-hara they control the boundaries of the community, monitoring entrances and identifying insiders from outsiders. Many of the practices recall traditional futuwwah acts. ${ }^{107}$ In dealing with violations of the moral code, the Jama ${ }^{c}$ a issued warnings. For instance, in the late 1980s and early 1990s, the Jama ${ }^{c}$ a dealt with violations of the moral code by issuing warnings to the "violators" and calling them to the mosque for disciplinary meetings. The emir or the group instructed transgressors on correct practice and advised reform. Failure to comply was met with punishment which included beating and flogging. Jama ${ }^{c}$ a members appropriate the role of protecting women and safeguarding their sharaf (chastity).

104 I thank Diya' Rashwan for bringing this to my attention. See Abd al-Fatah and Rashwan eds., Taqrir al-Hala al-Dinniya 1996.

105 Ruz al-Yusuf, 19 December 1988. 106 Mubarak, al-Irhabiyun Qadimun.

107 The view that the militants are contemporary manifestations of the zu $\mathrm{r}$, futuwwa, and other outlaws was put forward by Muhammad Nur Farhat, and has influenced a number of analysts. See his "al- ${ }^{c}$ Unf al-Syiasi wa al-Jama at al-Hamishiya: Dirasat fi al-Tarikh al-Ijtima i i," [Political Violence and the Marginal Groups: A Study in Social History] in the Proceedings of the Conference $a l-{ }^{c}$ Unf al-Siyasi fi al-Watan al-Arabi [Political Violence in the Arab Nation], ed. Usama alGhazali Harab (Amman: Arab Thought Forum, 1987), cited in both Mu ${ }^{c}$ awad, al-Hamishiyun, and Mubarak, al-Irhabiyun Qadimun. 
In imposing control in the home, the Jama a seemed to operate a system of surveillance which allowed it to detect illicit relations between men and women in the neighbourhood. ${ }^{108}$ In Ain Shams, alleged illicit conduct was punished by public flogging. In Imbaba, the Jama a attacked flats where "immoral" acts were reputed to be taking place and charges were made against the inhabitants. Furthermore, there are reports of neighbourhood fights between Islamist activists and coffee shop and video-club proprietors. ${ }^{109}$ These events indicate not only that a different lifestyle was pursued by some of the residents, but also that those who differed were not easily deterred by the Jama a's practices.

The Jama a members' interventions extend to economic activities and other types of social relations: they oversee market activities, and engage in neighbourhood brawls in their role as mediators and arbiters. It should be recalled that the various futuwwa practices lie on a continuum from protective, integrative functions at one extreme, to the destabilising, disintegrative activities associated with the gang leader-the baltagi (thug) type-at the other. ${ }^{110}$ According to some commentators, Shaykh Jabir, the Imbaba emir, was a baltagi and not a religious leader. ${ }^{111}$ There is an ambiguity in the role of the defenderprotector who uses bullying and intimidation-popular acceptance of this behaviour takes into account the level of violence used and the goals being pursued. In these roles, we see the practices of the old quarters reappearing. However, there are limits to the Islamists' success in redefining popular practices. The extremism in tone and action which tends to accompany the Islamists' assumption of these roles contradicts the no-fuss spirit of awlad al-bal$a d$ (sons of the country), resulting in a loss of popular support for the Jama ${ }^{c} a{ }^{112}$ Thus, the dynamics of their popular insertion are more complex than they appear at first sight.

Islamists anchor themselves in spaces which, because of their characteristics of autonomy, informality and self-regulation, are open to oppositional activities. Islamists are thus enmeshed in the web of social relations found in these areas. They may have a program of change, but they are likely to lose ground if they push too far on certain issues. There are rules governing their reciprocal relations with the communities. As participants in familial, economic, and religious networks they gain community support for their activities in facing the government. Yet their use of force to apply a strict or puritanical code contradicts pop-

108 Ruz al-Yusuf, 19 December 1988, 13-16.

109 Al-Taqrir al-Istratiji al-Arabi 1992 [The Arab Strategic Report 1992] (Cairo: Markaz alDirasat al-Syiasyiya wa al-Istratijiya, 1993).

110 On the baltagi type see El-Messiri, "The Role of the Futuwwa," 248.

111 This is the view of some Egyptian commentators and journalists. See for example Salah Muntasir, "Mas'uliyat al-Makan," (The Responsibility of Space), Al-Ahram al-Dawli, 15 December 1992.

112 On the concept of Ibn al-Balad see Sawsan el-Messiri, Ibn al-Balad: A Concept of Egyptian Idenity (Leiden: Brill,1979) 
ular norms of tolerance and moderation. In support of the first proposition, I draw on the facts surrounding cases of confrontation with the state. In Ain Shams, the Jama $^{\text {' }}$ a relied on familial networks to supply the numbers needed for the demonstrations that followed the August and December 1988 standoffs with the police. It has been reported that the December conflict started as a dispute between several vendors and a single police officer which escalated when the police used this as a pretext to regain control of the area, thereby drawing in the Jama ${ }^{c}$ a. Thus, the Islamists' involvement overlaps with popular antagonism towards authority. In Imbaba, neighbourhood youths of the futuwwa type joined the Jama ${ }^{c} a$ and provided the needed muscle in clashes with the police in 1992.

This pattern of clashes is also found in other instances of social violence which do not involve the Jama ${ }^{c}$ a. A recent study of violence in Egypt between 1967 and 1992 shows that popular riots and demonstrations often begin as conflicts with the police. In these cases, police mistreatment of citizens tends to spark off urban riots, in which the residents of the victim's neighbourhood are mobilised. They usually march on the police station involved and clash with the officers. Such incidents have occurred in popular quarters such as Sayyida Zaynab, Ataba and al-Madabigh. The crowd is often composed mainly of hirafiyyin (plumbers, bakers, and construction workers, for example). ${ }^{113}$ Popular resentment towards the police is undoubtedly intensifying, as police brutality has become the norm. A standard repertoire of urban unrest appears to be developing: street clashes with the police in response to excessive police force and arbitrary arrestation, followed by marches on the police station and ending in additional arrests. No doubt, this patterning of relations has resulted in the transformation of some of Cairo's police stations into veritable fortresses. ${ }^{114}$

Strong popular engagement in Islamist clashes with the police are evidenced in the fact that in both the Imbaba and Ain Shams cases the confrontation extended over periods of several days to several weeks, and required the deployment of large numbers of police personnel. The Ain Shams operations were executed in two stages - in August and December of 1988. After gaining control of the Imbaba territory, a police unit was stationed in the area for some time. "Combing out" operations continue in these areas, despite the large numbers of militants arrested. State action against the militants has comprised the repossession of the mosques and the closure of the zawiya, in addition to campaigns aimed at discrediting the militants and undermining their popular appeal. Here we have clues as to the Islamists' ability to capture oppositional potential and channel it into organised social activism beyond what Asef Bayat terms "quiet

\footnotetext{
113 Hussein Ali Abd al-Salam, Violence in Egypt, 1967-1992. Unpublished Ph.D. dissertation (Politics Department, University of Exeter, 1997).

114 The Maadi station which was the target of a 1986 uprising of central security soldiers has been fortified, and the main street leading to it has a roadblock and police guards. The Helwan station, which is on a main thoroughfare, is surrounded by high walls, with armed soldiers guarding the entrance.
} 
encroachment." 115 According to Bayat, the absence of structures for popular collective action accounts for the lack of a sustained challenge similar to that seen in Iran's shantytown dweller movements. The latter involved intense and prolonged mobilisation and protests. However, if we take into account the standoffs in Imbaba and Ain Shams we find that the structures discussed above provided the bases for widening the Islamists' conflict with the government to include greater segments of the population.

There are macrostructural elements which favour popular engagement in support of the Islamists. These do not arise out of alienation and uprootedness, but out of the new dynamics of state-society relations. It should be recalled that formal political organisations are ineffective in representing or mobilising the people. The social/moral contract between the people and the state of the Nasserist period has weakened, if not dissolved. The deal organised around the suspension of citizens' political rights in exchange for social rights is no longer operative. Today, there is little in the way of social benefit coming from the state. Increasingly, the people have to depend on their own resources, and a gradual process of disengagement is taking place. The corporatist structures are being dismantled, and with them the people's side of the bargain.

Before further examining the limitations on the Jama 'a's ability to transform itself into a full-fledged popular movement, I would like to underline the elements of organisation which can help it do so. The Jama 'a operates as a transneighbourhood group through a network of mosques and flats, particularly in the new quarters and some of the old quarters. In the records from the Jihad trial, we find that potential recruits were taken from their neighbourhood mosques to attend mosques in other neighbourhoods, in order to hear the emir/preacher. There are also indications that a level of coordination exists among the different neighbourhood cells of the Jama ${ }^{c}$ a. The active members enjoy a degree of mobility, and are able to relocate from one neighbourhood to another with the help of other Jama a members. These elements of their organisational structure are important for any attempt to establish a citywide popular movement. ${ }^{116}$ However, the group experiences both internal, ideological and, by extension, operational,constraints, and external constraints that come with the government's policy of encirclement.

If the advocacy of anti-government violence is a source of attraction for the youths, the policy of social violence detracts from their ability to reach wider segments of the population. The popular cultural practice of providing satr (protection or cover) to an errant member of the community is a factor in approaching social and religious transgressions in a discrete manner. Peaceful avenues of conflict resolution emerge out of a desire to avoid division and the

115 Asef Bayat, "Cairo's Poor: Dilemmas of Survival and Solidarity," Middle East Report 27, 1 (Winter 1997): 2-6, 12.

${ }^{116}$ In negotiations with the state, the Jama a demands tend to centre on the government keeping its hands off their mosques. See Mubarak, "Ba ${ }^{c} \mathrm{~d}$ Indhar al-Suyah." 
entrenchment of animosities. Thus, the Jama 'a's public flogging of violators denies them satr and brings shame on individuals and their families. ${ }^{117} \mathrm{Re}$ strictions on listening to music and celebrating weddings are likely to be viewed as intolerant. The resilience of peaceful modes for regulating moral violations appears at this stage as a factor in making militant Islamism less appealing. Finally, the extreme violence which characterises the attacks on tourists and Copts in the last few years, and particularly the Luxor massacre, have brought shock and condemnation from all sectors of society. ${ }^{118}$

The question of violence implied in the jihad principle may, in the end, represent what Gehad Auda sees as a paradox for the militants. ${ }^{119}$ Their advocacy of exercising jihad to change un-Islamic practices has involved dispersed violent action, which lacks direction and brings chaos. In principle, anyone can engage in jihad, and this wrests control away from the hands of the leadership. The lawlessness of this type of situation, as noted above, is not always constrained by popular norms, because some Islamist principles clash with these norms. Finally, we should note the state's involvement in discrediting these acts as un-Islamic. State 'ulama have mobilised on a number of occasions to show the deviation of the militants from the "true" understanding of religion. Further, the government is pursuing a policy of cultural Islamisation through religious television programs and newspapers. This constitutes an attempt at constructing an alternative Islamic view-one focused on rituals and appearances. ${ }^{120}$ The question of whether this type of Islamisation would marginalise the militants or serve to reinforce their ranks is contingent on how the various forces involved position themselves in response.

TOWARDS A CONCLUSION: IS MILITANT ISLAMISM A PROTEST MOVEMENT OF THE POPULAR CLASSES?

This paper has attempted to show the popular dimensions of contemporary Islamism by underlining the socio-spatial determinants at work. It highlights the

117 The idea of satr is deployed in the face of compromising situations in which a person commits a moral indiscretion. Norms of social control necessitate the application of sanctions to such indiscretions. However, the safeguarding of reputation, loyalty and solidarity translate into a common interest among members of a family or group to keep certain indiscretions from becoming public. Satr/protection is deployed for this purpose. For a discussion of the rules of sanction and mediation see Andrea B. Rugh, Family in Contemporary Egypt (Syracuse: Syracuse University Press, 1984), 157-58.

118 There is dissension within the movement itself with regard to using this level of violence. The historic leadership in prison has called for a truce but has been disregarded. The extreme acts have been perpetrated by members of cells in Upper Egypt who, following the call for a truce, shifted allegiance to the overseas leadership. See Hisham Mubarak, "The Violence of Despair," Cairo Times, vol. 1, 21 (11-24 December 1997).

119 "The 'Normalization' of the Islamic Movement in Egypt from the 1970s to the Early 1990's," in Accounting for Fundamentalism, eds. Martin W. Marty and R. Scott Appleby (Chicago, University of Chicago Press, 1994).

120 For a discussion of this process see Salwa Ismail, "Confronting the Other: Identity, Culture, Politics and Conservative Islamism in Egypt," International Journal of Middle East Studies 30, 2 (1998): 199-225. 
spatial grounding of Islamism in the urban setting and points to a transformation in the social composition of the membership. The occupational profile of the members testifies to the particular socioeconomic setting from which they are drawn, and the particular social relations and networks within which they operate. These factors support the argument for the popular dimensions of the movement. In fact, the Islamist mode of action has responded to these determinants; moving into neighbourhoods, basing themselves in mosques, zawiyas, and flats, and engaging in social work and awareness-raising activities. These popular dimensions are undermined by an element of ideological practice, that of al-amr bil ma ruf wa al-nahy an al-munkar, which, in certain respects, merges with popular traditions, while contradicting them in others. The emerging picture is that the Jama ${ }^{c}$ a members are neither uprooted nor alienated. They are part of the social fabric. They may pull it in extreme directions, but they are woven within it. The use of violence to oppose the government or undermine its respectability gives vent to popular grievances, but extreme violence is likely to appear senseless.

The mobilisational potential of militant Islamism seems to lie in its ability to ground its ideological principles in the social antagonisms and the oppositional positions that are part of the urban landscape. The Islamists' activism and appropriation of space recall popular traditional practices and reinscribe historical modes of social organisation. To this extent, they conform to the people's perceptions of authenticity. In order to expand their popular support, they must operate within the socio-spatial framework of the communities. The Islamists' insertion into this setting has so far been beset by limitations because of constant government crackdowns and their own limited scope of ideological manoeuvrings. 